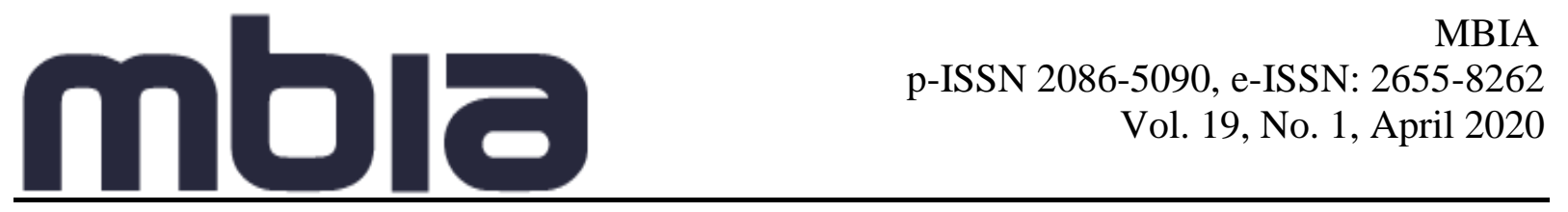

\title{
PENGARUH DISIPLIN KERJA DAN PEMBERIAN KOMPENSASI TERHADAP KINERJA KARYAWAN BAGIAN PENJUALAN DI PT. SURYA TIMUR SAKTI JATIM
}

\author{
Novianto Eko Nugroho \\ Sekolah Tinggi Ilmu Ekonomi Indonesia Surabaya \\ noviantoekonugroho@stiesia.ac.id
}

\begin{abstract}
Employee performance is a form of performance in terms of quality and quantity achieved by an employee in carrying out their duties in accordance with the responsibilities given to him. Improving employee performance is desirable both from the employer and workers for self-development and promotion of the position. The purpose of this study is to determine the effect of work discipline and compensation for employee performance in sales. This research method uses quantitative methods with the type of explanatory research. The subjects of this study were all sales employees of PT. Surya Timur Sakti East Java in Surabaya, amounting to 107 active employees. To test the effect between variables used multiple linear regression analysis method. The results showed that the presence of a positive and significant effect simultaneously between variables of work discipline and compensation for employee performance, while partially the variables of work discipline and compensation had a positive and significant effect on employee performance.
\end{abstract}

Keywords : Work Discipline, Compensation, Performance

\begin{abstract}
Abstrak
Kinerja karyawan merupakan kinerja adalah bentuk hasil kerja secara kualitas dan kuantitas yang dicapai oleh seseorang karyawan dalam melaksanakan tugasnya sesuai dengan tanggung jawab yang diberikan kepadanya. Peningkatan kinerja karyawan merupakan hal yang diinginkan baik dari pihak pemberi kerja maupun para pekerja untuk pengembangan diri dan promosi jabatan Tujuan dalam penelitian ini adalah untuk mengetahui pengaruh disiplin kerja dan pemberian kompensasi terhadap kinerja karyawan bagian penjualan. Metode penelitian ini menggunakan metode kuantitatif dengan tipe penelitian eksplanatif. Subjek penelitian ini adalah seluruh karyawan bagian penjualan PT. Surya Timur Sakti Jatim di Surabaya yang berjumlah 107 orang karyawan aktif. Untuk menguji pengaruh antar variabel digunakan metode analisis regresi linier berganda. Hasil penelitian menunjukkan bahwa adanya pengaruh positif dan signifikan secara simultan antara variabel disiplin kerja dan pemberian kompensasi terhadap kinerja karyawan, sedangkan secara parsial variabel disiplin kerja dan pemberian kompensasi berpengaruh positif dan signifikan terhadap kinerja karyawan.
\end{abstract}

Kata kunci : Disiplin Kerja, Kompensasi, Kinerja 


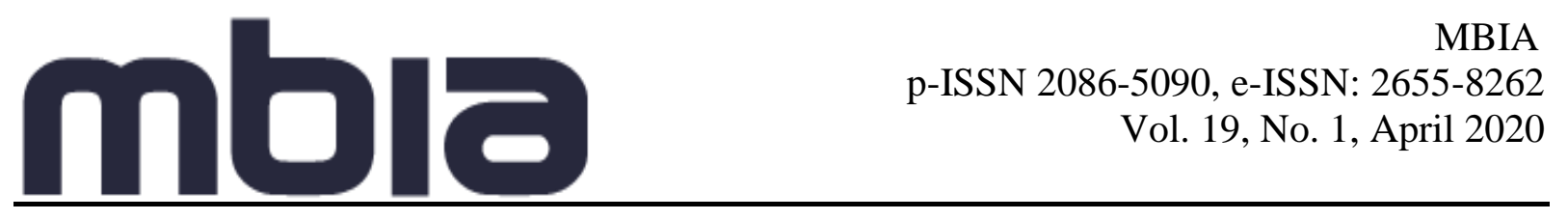

\section{PENDAHULUAN}

Persaingan bisnis otomotif dalam era digital sekarang ini semakin ketat dan kompetitif diiringi dengan pertumbuhan dan perkembangan kebutuhan masyarakat akan transportasi yang murah dan efisien. Dengan terus berkembangnya kebutuhan masyarakat menutut produsen dan distributor otomotif untuk menciptakan inovasi produk yang digemari masyarakat. Kesuksesan perusahaan dalam meraih predikat Market Leader ditentukan oleh simbiosis mutualisme antara produsen otomotif dengan masyarakat sebagai konsumen. Pertumbuhan dan perkembangan suatu perusahaan tidak akan terlepas dari peranan penting karyawan. Karyawan adalah orang penjual jasa (pikiran atau tenaga) dan mendapat kompensasi yang besarnya telah ditetapkan terlebih dahulu (Hasibuan dalam Karimah, 2012).

Peranan disiplin kerja sangat penting untuk meningkatkan pertumbuhan organisasi karena digunakan untuk memotivasi karyawan agar dapat melaksanakan pekerjaan dengan baik. Kesuksesan suatu perusahaan tidak hanya faktor disiplin kerja semata terdapat faktor lain yang mempengaruhi kinerja karyawan, yaitu pemberian kompensasi. Pemberian kompensasi menjadi agenda penting dalam kegiatan perusahaan, karena karyawan akan dapat lebih terpuaskan dan termotivasi untuk mencapai sasaran-sasaran perusahaan. Disiplin kerja sangat penting untuk pertumbuhan organisasi karena di gunakan untuk memotivasi karyawan agar dapat melaksanakan perkerjaan dengan baik.

Disiplin dalam suatu perusahaan harus ditegakkan karena Hasibuan (2014: 194) menyatakan bahwa tujuan perusahaan dapat diwujudkan dengan menegakkan disiplin. "Disiplin kerja digunakan sebagai alat untuk berkomunikasi dengan karyawan sehingga karyawan mau mengikuti aturan yang telah ditetapkan". Implementasi disiplin kerja dalam lingkungan kerja perusahaan akan membantu untuk mendidik karyawan untuk mentaati peraturan, prosedur, dan kebijakan yang ada. Unsur utama dari pelaksanaan disiplin kerja untuk mengoreksi penampilan kerja agar peraturan kerja dapat diberlakukan secara konsisten, tidak bersifat menghakimi dalam memberlakukan hukuman atas tindakan indisipliner. Kepatuhan karyawan dalam melaksanakan disiplin kerja akan membantu meningkatkan kinerja karyawan dalam melaksanakan disiplin kerja dan menjamin terlaksananya operasional perusahaan dengan baik dan lancar.

Selain disiplin kerja terdapat faktor lain yang mempengaruhi kinerja karyawan, yaitu pemberian kompensasi. Pemberian kompensasi menjadi agenda penting dalam kegiatan perusahaan, karena karyawan akan dapat lebih terpuaskan dan termotivasi untuk mencapai sasaran-sasaran perusahaan. Hal ini didukung oleh penjelasan Nawawi (2008: 315), bahwa kompensasi merupakan bentuk penghargaan atau ganjaran yang diberikan oleh organisasi/perusahaan kepada para pekerja yang memikul kewajiban dan tanggung jawab melaksanakan pekerjaan. Pemberian kompensasi yang benar dan memadai akan memberikan manfaat positif tidak hanya bagi karyawan, tetapi juga bagi perusahaan. Pemberian kompensasi yang benar dan memadai akan menurunkan tingkat perputaran karyawan dan biaya perekrutan karyawan baru dapat ditekan, sehingga menguntungkan bagi perusahaan. 
Kebutuhan peningkatan kinerja karyawan, terdapat dua faktor yang di anggap mempengaruhi tinggi rendah tingkat kinerja karyawan, yaitu bentuk disiplin kerja dan pemberian kompensasi. Menurut Mangkunegara (2006:67), kinerja karyawan atau yang sering disebut sebagai prestasi kerja merupakan hasil kerja secara kualitas dan kuantitas yang dicapai oleh seorang pegawai dalam melaksanakan tugasnya sesuai dengan tanggung jawab yang diberikan kepadanya.

PT. Surya Timur Sakti Jatim merupakan salah satu perusahaan distributor sepeda motor merek Yamaha di wilayah Jawa Timur, yang terus meningkatkan kinerja karyawannya secara keseluruhan. Namun tidak mudah untuk mencapai tingkat kinerja yang sesuai dengan keinginan manajemen perusahaan. Sesuai dengan data yang diperoleh dari bagian penjualan diketahui tingkat penjualan dan realisasi penjualan oleh PT. Surya Timur Sakti Jatim adalah sebagai berikut :

Tabel 1

Penjualan dan Realisasi

PT. Surya Timur Sakti Jatim

\begin{tabular}{|c|c|c|c|c|c|}
\hline Tahun & $\begin{array}{c}\text { Jumlah } \\
(\text { Orang })\end{array}$ & $\begin{array}{c}\text { Target } \\
\text { Penjualan }\end{array}$ & $\begin{array}{c}\text { Realisasi } \\
\text { Penjualan }\end{array}$ & $\begin{array}{c}\text { Persentase } \\
\text { Penjualan (\%) }\end{array}$ & $\begin{array}{c}\text { Tingkat } \\
\text { Produktivitas }\end{array}$ \\
\hline 2010 & 89 & 480 & 423 & 88,12 & 4,75 \\
\hline 2011 & 95 & 970 & 900 & 92,78 & 9,47 \\
\hline 2012 & 100 & 1020 & 1202 & 117,84 & 12,02 \\
\hline 2013 & 98 & 1040 & 990 & 95,19 & 10,10 \\
\hline 2014 & 107 & 1200 & 850 & 70,83 & 7,94 \\
\hline 2015 & 107 & 1100 & 750 & 68,18 & 7,01 \\
\hline
\end{tabular}

Sumber : PT. Surya Timur Sakti Jatim, 2015 (Data diolah)

Berdasarkan data tabel 1 bahwa dalam kegiatan penjualan sepeda motor merek Yamaha dari tahun 2010 sampai dengan tahun 2015 mengalami fluktuasi. Pada tahun 2012 perusahaan mampu melebihi target yang ditetapkan, yaitu 1202 unit dari target penjualan sebanyak 1020 unit atau sebesar $117,84 \%$. Sedangkan pada tahun-tahun berikutnya perusahaan tidak mampu mencapai targetnya, bahkan pada tahun 2013 sampai 2015 penjualan mengalami penurunan yang cukup signifikan, yaitu target penjualan sebanyak 1040 unit yang terealisasi hanya 990 unit atau sebesar 95,19\% dan 850 unit dari target yang di tetapkan, yaitu 1200 atau sebesar 70,83 serta 750 unit dari target yang ditetapkan, yaitu 1100 atau sebesar 68,18\%. Data realisasi karyawan bagian penjualan pada PT. Surya Timur Sakti Jatim sampai tahun 2015 mengalami penurunan sampai $68,18 \%$ dan berada dibawah target penjualan yang telah ditetapkan. Dari data tersebut menunjukkan bahwa terjadi penurunan selama periode 2013 sampai 2015. Dimana penurunan kemampuan menjual produk yang ada pada perusahaan menunjukkan kinerja karyawan yang mengalami penurunan dari tahun 2013 dan 2015.

Melihat hasil kinerja yang rendahnya disebabkan beberapa faktor berupa disiplin kerja dan kompensasi yang diterima oleh karyawan dirasakan kurang baik. Disiplin pegawai adalah perilaku seseorang dengan peraturan, prosedur kerja yang ada atau disiplin adalah sikap, tingkah laku, dan perbuatan yang sesuai dengan peraturan dari organisasi baik tertulis maupun yang tidak tertulis (Sutrisno, 2013:89). 


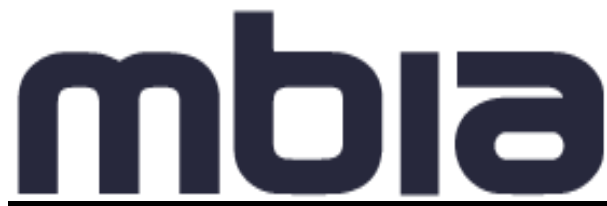

MBIA

p-ISSN 2086-5090, e-ISSN: 2655-8262

Vol. 19, No. 1, April 2020

Hal ini didukung Arianto (2013:192) yang menjelaskan kedisiplinan dalam suatu organisasi harus ditegakkan, karena tanpa dukungan kedisiplinan karyawan yang baik, maka sulit untuk mewujudkan tujuan dari organisasi tersebut. Hal yang paling dasar dalam kedisiplinan karyawan adalah manajemen waktu, dalam hal ini yaitu jam kerja. Apabila waktu tersebut sering dilanggar, dapat dikatakan bahwa para karyawan menjadi tidak disiplin sehingga mengakibatkan penurunan kinerja dan kualitas kerja karyawan. Bentuk kedisiplinan pada penelitian ini dapat ditunjukkan dengan tingkat kehadiran karyawan. Data sehubungan dengan bentuk kedisiplinan pada penelitian ini dapat dilihat seperti pada tabel berikut ini :

Tabel 2

Rekapitulasi Absensi Karyawan Bagian Penjualan PT. Surya Timur Sakti Jatim

\begin{tabular}{|l|c|c|c|c|c|c|c|c|c|}
\hline \multirow{2}{*}{ Bulan } & \multirow{2}{*}{ Jumlah } & \multicolumn{9}{|c|}{ Keteranqan Ketidakhadiran } \\
\cline { 3 - 11 } & & \multicolumn{2}{|c|}{ Izin } & \multicolumn{2}{c|}{ Cuti } & \multicolumn{2}{c|}{ Sakit } & \multicolumn{2}{c|}{ Absen } \\
\cline { 3 - 11 } & $\mathrm{F}$ & $\%$ & $\mathrm{~F}$ & $\%$ & $\mathrm{~F}$ & $\%$ & $\mathrm{f}$ & $\%$ \\
\hline Januari & 125 & 6 & 2.32 & 9 & 3.47 & 7 & 2.70 & 8 & 3.01 \\
\hline Februari & 125 & 8 & 3.01 & 10 & 3.70 & 6 & 2.32 & 9 & 3.47 \\
\hline Maret & 115 & 11 & 4.05 & 8 & 3.01 & 9 & 3.47 & 9 & 3.47 \\
\hline April & 109 & 9 & 3.47 & 9 & 3.47 & 8 & 3.01 & 11 & 4.05 \\
\hline Mei & 109 & 12 & 4.45 & 11 & 4.05 & 10 & 3.70 & 7 & 2.70 \\
\hline Juni & 112 & 8 & 3.01 & 9 & 3.47 & 9 & 3.47 & 6 & 2.32 \\
\hline Juli & 109 & 10 & 3.70 & 7 & 2.70 & 7 & 2.70 & 10 & 3.70 \\
\hline Aqustus & 111 & 9 & 3.47 & 9 & 3.47 & 6 & 2.32 & 9 & 3.47 \\
\hline September & 115 & 8 & 3.01 & 12 & 4.42 & 9 & 3.47 & 13 & 4.77 \\
\hline Oktober & 110 & 11 & 4.05 & 8 & 3.01 & 8 & 3.01 & 10 & 3.70 \\
\hline November & 109 & 7 & 2.70 & 10 & 3.70 & 7 & 2.70 & 8 & 3.01 \\
\hline Desember & 107 & 10 & 3.70 & 9 & 3.47 & 9 & 3.47 & 9 & 3.47 \\
\hline
\end{tabular}

Sumber : PT. Surya Timur Sakti Jatim, 2015 (Data diolah)

Berdasarkan tabel 2 menunjukkan tingkat keterlambatan dan absensi karyawan. Dari hasil persentase tersebut diatas menunjukkan tingkat disiplin karyawan yang perlu mendapatkan perhatian karena dibawah standar yang sudah ditentukan dalam aturan perusahaan. Sesuai aturan yang ada di PT. Surya Timur Sakti Jatim hasil persentase keterlambatan dan absensi yang masih bisa ditoleransi pertahunnya adalah 0\%-3\%. Kurangnya disiplin karyawan akan mempengaruhi kinerja karyawan dan jalannya operasional perusahaan. Tinggi atau rendahnya tingkat kehadiran karyawan akan berpengaruh terhadap kualitas dan kuantitas tingkat penjualan.

Selanjutnya faktor lain yang perlu diperhatikan dapat mempengaruhi kinerja karyawan adalah pemberian kompensasi karyawan. Menurut Simamora (2004:442) mendefinisikan :

"Kompensasi (Compensation) meliputi imbalan finansial dan jasa nirwujud serta tunjangan yang diterima oleh para karyawan sebagai bagian dari hubungan kepegawaian. Kompensasi merupakan apa yang diterima oleh para karyawan sebagai ganti kontribusi mereka kepada organisasi”.

Pemberian kompensasi yang tepat dan memadai akan memberikan manfaat positif tidak hanya bagi karyawan, tetapi juga bagi perusahaan serta mampu menurunkan tingkat perputaran karyawan (Turn Over Employee) dan biaya perekrutan karyawan baru dapat ditekan sehingga dapat meningkatkan keuntungan bagi perusahaan. Pemberian berbagai kompensasi menjadi salah satu motivasi yang dapat meningkatkan semangat kerja karyawan yang apabila diarahkan dengan baik dan benar. Berkaca dari sisi gaji yang diberikan oleh perusahaan telah berada diatas upah minimum provinsi (UMP), namun dirasakan masih 
kurang untuk mencapai hidup layak. Hal ini yang diinginkan oleh karyawan adalah seperti adanya bonus akhir tahun yang cukup tinggi, tunjangan yang baik untuk anak dan istri. Kompensasi yang kurang tersebut menjadikan karyawan menjadi menurun kinerjanya.

Data sehubungan dengan kompensasi/insentif yang diterima oleh karyawan di PT. Surya Timur Sakti Jatim adalah sebagai berikut :

Tabel 3

Insentif Karyawan bagian Penjualan PT. Surya Timur Sakti Jatim

\begin{tabular}{|c|c|c|c|c|}
\hline \multirow{2}{*}{ No. } & \multirow{2}{*}{ Jabatan } & \multicolumn{3}{|c|}{ Besar Insentif } \\
\hline & & $96-100 \%$ & $89-95 \%$ & $85-90 \%$ \\
\hline 1 & Kepala Penjualan & 2.089 .000 & 1.950 .000 & 1.850 .000 \\
\hline 2 & Sales Supervisor & 1.650 .000 & 1.550 .000 & 1450.000 \\
\hline 3 & Counter sales & 750.000 & 650.000 & 550.000 \\
\hline 4 & Salesmen & 540.000 & 440.000 & 350.000 \\
\hline
\end{tabular}

Sumber : PT. Surya Timur Sakti Jatim, 2015 (data diolah)

Berdasarkan tabel 3 menunjukkan jabatan dan besaran insentif yang diberikan kepada karyawan bagian penjualan di PT. Surya Timur Sakti Jatim dalam bentuk finansial. Kompensasi finansial yang diberikan berupa gaji pokok, THR dan tunjangan kesehatan. PT. Surya Timur Sakti Jatim memberikan insentif kepada setiap bagian, namun pemberiannya merujuk dari jabatan dan besarnya pencapaian prestasi kerja yang dicapai setiap karyawan. Sistem pemberian insentif menggunakan sistem pembagian keuntungan dimana sejumlah keuntungan yang didapat dari penjualan dibagikan perjabatan. Apabila jabatan dan pencapaian yang diemban oleh karyawan itu tinggi, maka insentif yang diterima juga besar.

\section{KAJIAN PUSTAKA}

\section{Displin Kerja (Work Discipline)}

Didalam kehidupan sehari-hari banyak yang mengartikan disiplin sebagai ketaatan seseorang atau sekelompok terhadap peraturan yang telah ditetapkan. Disiplin dalam suatu perusahaan harus ditegakkan karena Hasibuan (2014: 194) menyatakan bahwa tujuan perusahaan dapat diwujudkan dengan menegakkan disiplin. "Disiplin kerja digunakan sebagai alat untuk berkomunikasi dengan karyawan sehingga karyawan mau mengikuti aturan yang telah ditetapkan". Menurut Hani Handoko dalam Apriani (2019 : 530) "Disiplin merupakan kegiatan manajemen untuk menjalankan standar organisasional."

Disiplin karyawan yang baik akan membuat organisasi mencapai tujuannya lebih mudah (Sinambela, 2016:335). Hasibuan (2014:193) menjelaskan bahwa, "Disiplin adalah kesadaran dan kemauan seseorang untuk mematuhi semua aturan perusahaan dan norma sosial yang berlaku. Disiplin didefinisikan ketika karyawan selalu datang dan pulang tepat waktu, melakukan semua pekerjaan dengan baik, dan mematuhi peraturan perusahaan dan norma sosial yang berlaku. 


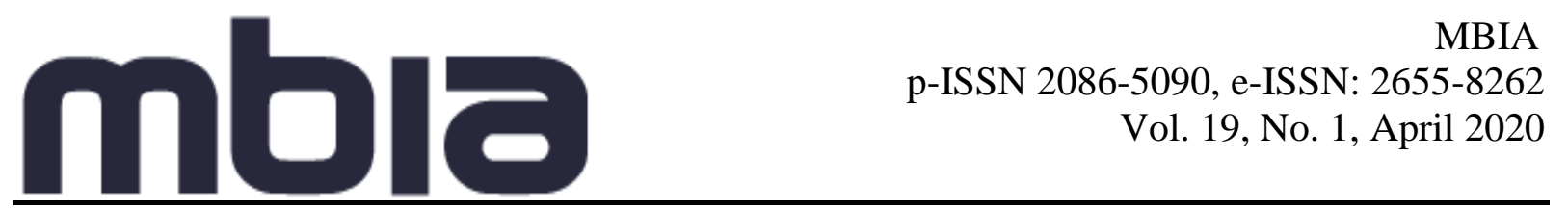

Disiplin kerja dapat diukur melalui hal-hal berikut (Hasibuan, 2014: 194) yaitu tujuan dan kemampuan, model pemimpin, gaji, keadilan, waskat (kontrol terpadu), sanksi hukuman, keteguhan, hubungan kemanusiaan.

Menurut Lateiner dalam Sutrisno (2011 : 87), “disiplin merupakan tindakan manajemen untuk mendorong para anggota organisasi memenuhi tuntutan berbagai ketentuan tersebut. Tanpa disiplin yang baik, sulit bagi organisasi mencapai hasil yang optimal. Kedisiplinan harus ditegakkan dalam suatu organisasi perusahaan, karena tanpa dukungan disiplin karyawan yang baik, maka sulit bagi perusahaan untuk mewujudkannya. Jadi kedisiplinan adalah kunci keberhasilan suatu perusahaan mencapai tujuan.

\section{Kompensasi (Compensation)}

Kompensasi didefinisikan oleh para pakar secara beragam. Menurut Henry Simamora (2004:442) mendefinisikan, "Kompensasi (compensation) meliputi imbalan finansial dan jasa nirwujud serta tunjangan yang diterima oleh para karyawan sebagai bagian dari hubungan kepegawaian. Kompensasi merupakan apa yang diterima oleh para karyawan sebagai ganti kontribusi mereka kepada organisasi”.

Menurut Rivai (2009:357) Kompensasi merupakan sesuatu yang di terima karyawan sebagai pengganti kontribusi jasa mereka pada perusahaan. Hal ini sependapat dengan Nawawi (2008:315) menjelaskan kompensasi sebagai bentuk penghargaan atau ganjaran yang diberikan oleh organisasi/perusahaan kepada para pekerja yang memikul kewajiban dan tanggung jawab melaksanakan pekerjaan. Kewajiban dan tanggung jawab itu muncul karena antara kedua belah pihak terdapat hubungan kerja dalam organisasi/perusahaan. Sedangkan pekerjaan yang dihargai dan diberi ganjaran harus yang relevan sehingga memberikan kontribusi dalam usaha mewujudkan tujuan organisasi/perusahaan.

\section{Kinerja (Performance)}

Menurut Mangkunegara (2006:67) menyatakan bahwa kinerja adalah hasil kerja secara kualitas dan kuantitas yang dicapai oleh seseorang karyawan dalam melaksanakan tugasnya sesuai dengan tanggung jawab yang diberikan kepadanya.

Menurut Hasibuan (2005:105) berpendapat bahwa Kinerja adalah suatu hasil kerja yang dicapai seseorang dalam melaksanakan tugas-tugas yang dibebankan kepadanya yang didasarkan atas kecakapan, pengalaman, dan kesungguhan serta waktu.

\section{Pengukuran Kinerja (Performance Measurement)}

Menurut Young dalam Mangkunegara (2006:42) mendifinisikan pengukuran kinerja sebagai tindakan pengukuran yang dilakukan terhadap berbagai aktivitas dalam rantai nilai yang ada pada perusahaan. Hasil pengukuran tersebut digunakan sebagai umpan balik yang memberikan informasi tentang prestasi, pelaksanaan suatu rencana dan apa yang di perlukan perusahaan dalam penyesuaian-penyesuaian dan pengedalian. 
Pengukuran kinerja digunakan untuk memilih keberhasilan dan kegagalan pelaksanaan kegiatan sesuai dengan sasaran dan tujuan yang telah ditetapkan guna mewujudkan visi dan misi pemerintahan. Pengukuran kinerja merupakan hasil dari penelitian yang sistematis sesuai dengan suatu rencana yang telah di tetapkan dalam penyesuaian-penyesuaian dan pengendalian. Menurut Arkinso dalam Mangkunegara (2006:42) mengemukakan ciri-ciri pengukuran kinerja sebagai berikut :

1. Merupakan suatu aspek dari strategi perusahaan

2. Menetapkan ukuran kinerja melalui ukuran mekanisme komunikasi antar tingkatan manajemen.

3. Mengevaluasi hasil kinerja secara terus menerus guna perbaikan pengukuran kinerja pada kesempatan selanjutnya.

\section{Penilaian Kinerja (Performance Appraisal)}

Menurut Mondy (2008:257), penilaian kinerja (performance appraisal) adalah sistem formal untuk melihat dan mengevaluasi kinerja tugas individu atau tim. Penilaian kinerja mengacu kepada suatu sistem formal dan terstruktur yang digunakan untuk mengukur, menilai, dan mempengaruhi sifat-sifat yang berkaitan dengan pekerjaan, perilaku, dan hasil termasuk tingkat ketidakhadiran.

Menurut Hariandja (2007:195), tujuan dilakukannya penilaian untuk kerja secara umum adalah memberikan feedback kepada pegawai dalam upaya memperbaiki tampilan kerjanya dan upaya meningkatkan produktivitas organisasi dan secara khusus dilakukan dalam kaitannya dengan berbagai kebijaksanaan terhadap pegawai seperti untuk promosi, kenaikan gaji, pendidikan, dan latihan.

\section{KERANGKA KONSEPTUAL DAN HIPOTESIS PENELITIAN Kerangka Konseptual}

Kerangka konseptual dalam penelitian ini ditunjukkan pada gambar 1.

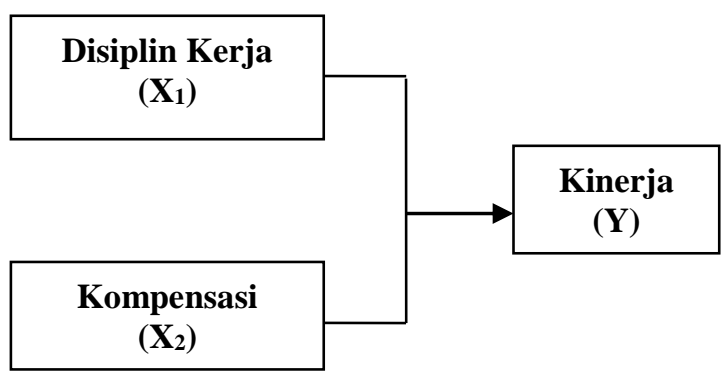

Gambar 1

Kerangka Konseptual Penelitian

\section{Hipotesis Penelitian}

Berdasarkan kerangka konseptual penelitian diatas, maka dapat ditentukan hipotesis pada penelitian ini sebagai berikut : 
H1 : Disiplin Kerja berpangaruh secara signifikan terhadap kinerja karyawan.

H2 : Kompensasi berpengaruh secara signifikan terhadap kinerja karyawan.

\section{METODE PENELITIAN}

Penelitian ini menggunakan metode kuantitatif survey (studi kasus) dengan tingkat eksplanasi deskriptif. Yaitu mendeskripsikan fenomena penerapan disiplin kerja dan pemberian kompensasi pada karyawan divisi penjualan. Selanjutnya melakukan analisa besaran nilai pengaruh disiplin kerja dan pemberian kompensasi terhadap kinerja karyawan (Aliya, 2019). Metode kuantitatif merupakan metode penelitian dengan data penelitian berupa angka-angka dan analisisnya menggunakan statistik (Sugiyono,2013). Alat analisa yang digunakan diharapkan akan dapat mengetahui adakah Pengaruh Disiplin Kerja dan kompensasi Terhadap Kinerja Karyawan. Pendekatan penelitian yang dilakukan adalah pendekatan potong lintang (cross sectional) yaitu dengan analisa data primer dan data sekunder saat penelitian.

Metode pengumpulan data yang digunakan adalah menggunakan kuesioner (Daftar pertanyaan) yaitu teknik pengumpulan data dengan menggunakan daftar pertanyaan yang telah disusun secara sistematis berhubungan dengan masalah yang ada dalam penelitian ini. Daftar pertanyaan kuesioner disusun untuk memperoleh data dan informasi tentang Disiplin Kerja dan kompensasi Terhadap Kinerja Karyawan. Jenis data yang dipergunakan dalam penelitian ini merupakan data primer, yaitu data yang diperoleh langsung dari responden tentang pengaruh mengenai Pengaruh Disiplin Kerja dan kompensasi Terhadap Kinerja Karyawan bagian Penjualan PT. Surya Timur Sakti Jatim Dalam penelitian ini terdapat definisi operasional variabel yang digunakan untuk pengukuran variabel disiplin kerja (X1), kompensasi (X2) dan variabel kinerja karyawan (Y).

\section{HASIL PENELITIAN}

Dalam penelitian ini diketahui menggunakan 107 responden karyawan bagian penjualan yang digunakan sebagai sampel penelitian, berdasarkan usia dapat diketahui sebagian besar berusia 21-30 tahun, dimana terdapat 59 orang responden $(69,4 \%)$. Berdasarkan jenis kelamin dapat diketahui sebagian besar adalah lalki-laki, dimana terdapat 59 responden mahasiswa $(69,4 \%)$. Berdasarkan tingkat pendidikan dapat diketahui sebagian besar karyawan berpendidikan Strata 1 (S1), dimana terdapat 35 orang responden $(41,2 \%)$. Berdasarkan lama bekerja dapat diketahui sebagian besar karyawan antara 1-5 tahun, dimana terdapat 46 orang responden $(54,1 \%)$.

\section{Analisis Regresi Linier Berganda}

Model analisis regresi linier berganda pada penelitian memiliki variabel bebas yaitu disiplin kerja dan pemberian kompensasi (X) terhadap variabel terikat yaitu kinerja karyawan (Y) sebagai berikut :

$$
\begin{gathered}
Y=a+b 1 X 1+b 2 X 2+e \\
Y=7.959+0,410 X_{1}+0.267 X_{2}
\end{gathered}
$$


Berikut penjelasan hasil analisis regresi linier berganda diuraikan sebagai berikut :

a. Konstanta $(\alpha)=7.959$, ini menunjukkan bahwa jika variabel Disiplin kerja dan Kompensasi di anggap konstan maka tingkat variabel kinerja Karyawan (Y) PT Alfa Scorpii Medan adalah sebesar 7.959

b. Koefisien $b_{1}\left(\mathrm{X}_{1}\right)=0.410$, menunjukkan bahwa variabel Disiplin Kerja berpengaruh positif terhadap Kinerja Karyawan atau dengan kata lain jika variabel Disiplin Kerja ditingkatkan maka Kinerja karyawan akan bertambah sebesar 0.410. Tanda Positif Pada Variabel Disiplin Kerja menunjukkan hubungan searah antara Variabel Disiplin Kerja Terhadap Kinerja Karyawan.

c. Koefisien $\mathrm{b}_{2}\left(\mathrm{X}_{2}\right)=0.267$, menunjukkan bahwa variabel Kompensasi berpengaruh secara positif terhadap kinerja karyawan. Dengan kata lain jika variabel Kompensasi ditingkatkan maka Kinerja karyawan akan bertambah sebesar 0.267. Tanda Positif Pada Variabel Kompensasi menunjukkan hubungan searah antara variabel Kompensasi terhadap Kinerja karyawan.

Tabel 4

Hasil Regresi Linear Berganda

\begin{tabular}{|c|c|c|c|c|c|c|c|c|}
\hline \multirow{2}{*}{\multicolumn{2}{|c|}{ Model }} & \multicolumn{2}{|c|}{$\begin{array}{l}\text { Unstandardized } \\
\text { Coefficients }\end{array}$} & \multirow{2}{*}{$\begin{array}{c}\begin{array}{c}\text { Standardized } \\
\text { Coefficients }\end{array} \\
\text { Beta }\end{array}$} & \multirow[t]{2}{*}{ T } & \multirow[t]{2}{*}{ Sig. } & \multicolumn{2}{|c|}{ Collinearity Statistics } \\
\hline & & B & Std. Error & & & & Tolerance & VIF \\
\hline \multirow[t]{3}{*}{1} & (Constant) & 7.959 & 3.014 & & 2.640 & .010 & & \\
\hline & Disiplin & .410 & .086 & .452 & 4.794 & .000 & .724 & 1.381 \\
\hline & Kompensasi & 267 & .075 & .333 & 3.539 & .001 & .724 & 1.381 \\
\hline
\end{tabular}

\section{UJI HIPOTESIS}

Uji Hipotesis Pengaruh Variabel Bebas Secara Parsial Terhadap Variabel Terikat (Uji t) Dari hasil dari uji t untuk masing-masing pengaruh variabel bebas (disiplin kerja, pemberian kompensasi) yang dihasilkan berpengaruh signifikan maka dapat disimpulkan bahwa hipotesis I yang menyatakan variabel disiplin kerja dan pemberian kompensasi berpengaruh signifikan terhadap kinerja karyawan bagian penjualan PT. Surya Timur Sakti Jatim.

Tabel 5

Hasil Uji Parsial (Uji t)

\begin{tabular}{|c|c|c|c|c|c|c|c|}
\hline \multirow[b]{2}{*}{ Model } & \multicolumn{2}{|c|}{$\begin{array}{l}\text { Unstandardized } \\
\text { Coefficients }\end{array}$} & \multirow{2}{*}{$\begin{array}{c}\text { Standardized } \\
\text { Coefficients } \\
\text { Beta }\end{array}$} & \multirow[t]{2}{*}{$T$} & \multirow[t]{2}{*}{ Sig. } & \multicolumn{2}{|c|}{ Collinearity Statistics } \\
\hline & B & Std. Error & & & & Tolerance & VIF \\
\hline 1 (Constant) & 7.959 & 3.014 & & 2.640 & .010 & & \\
\hline Disiplin & .410 & .086 & .452 & 4.794 & .000 & .724 & 1.381 \\
\hline Kompensasi & .267 & .075 & .333 & 3.539 & .001 & .724 & 1.381 \\
\hline
\end{tabular}

a. Dependent Variable: Kinerja

Sumber : Hasil Pengolahan SPSS 
Dari hasil tabel 5 koefisien korelasi pada variabel $\mathrm{X}_{1}$ yaitu disiplin yang memiliki nilai korelasi parsial tertinggi sebesar 4.794 dibandingkan dengan variabel bebas yang lain yaitu variabel kompensasi $\left(\mathrm{X}_{2}\right)$ sebesar 3.635, maka variabel disiplin merupakan variabel bebas yang paling dominan mempengaruhi variabel terikat yaitu kinerja karyawan bagian penjualan PT. Surya Timur Sakti Jatim.

\section{Uji Hipotesis Pengaruh Variabel Bebas Secara Simultan Terhadap Variabel Terikat (F)}

Berdasarkan nilai statistik pada tabel 6 hasil analisis regresi linier berganda, untuk membuktikan pengaruh dari disiplin kerja $\left(\mathrm{X}_{1}\right)$, pemberian kompensasi $\left(\mathrm{X}_{2}\right)$ terhadap kinerja karyawan (Y) diketahui bahwa nilai $\mathrm{F}$ hitung adalah sebesar 36.813 dengan nilai signifikansi 0,000. Dengan demikian karena nilai signifikansi 0,000 lebih kecil dari 0.05 maka disimpulkan disiplin kerja $\left(\mathrm{X}_{1}\right)$, pemberian kompensasi $\left(\mathrm{X}_{2}\right)$ memiliki pengaruh signifikan terhadap kinerja karyawan (Y).

Tabel 6

Hasil Uji Simultan (Uji F)

\begin{tabular}{|c|c|c|c|c|c|c|}
\hline \multicolumn{2}{|c|}{ Model } & $\begin{array}{l}\text { Sum of } \\
\text { Squares }\end{array}$ & $d f$ & $\begin{array}{l}\text { Mean } \\
\text { Square }\end{array}$ & $F$ & Sig. \\
\hline \multirow[t]{3}{*}{1} & Regression & 530.292 & 2 & 265.146 & 36.813 & .000 \\
\hline & Residual & 590.602 & 82 & 7.202 & & \\
\hline & Total & 1120.894 & 84 & & & \\
\hline
\end{tabular}

a. Predictors: (Constant), Kompensasi, Disiplin

b. Dependent Variable: Kinerja

Sumber : Hasil Pengolahan SPSS

Dari hasil uji $\mathrm{F}$ di atas maka disimpulkan untuk $\mathrm{H}_{0}$ ditolak dan $\mathrm{H}_{1}$ diterima. Dengan demikian hipotesis pertama penelitian diterima, dengan kata lain variabel disiplin kerja $\left(\mathrm{X}_{1}\right)$, pemberian kompensasi $\left(\mathrm{X}_{2}\right)$ secara simultan dihasilkan berpengaruh signifikan maka dapat disimpulkan bahwa hipotesis II yang menyatakan faktor disiplin kerja dan pemberian kompensasi secara simultan atau bersama-sama berpengaruh signifikan terhadap kinerja karyawan bagian penjualan PT. Surya Timur Sakti Jatim.

\section{Simpulan}

Penelitian ini bertujuan untuk mengetahui pengaruh Disiplin Kerja dan Kompensasi terhadap kinerja karyawan pada PT. Surya Timur Sakti Jatim. Berdasarkan hasil analisis dan pembahasan yang telah dipaparkan pada bab sebelumnya, maka dapat diambil kesimpulan sebagai berikut:

1. Hasil Uji $F$ bahwa Disiplin Kerja dan Kompensasi secara bersama-sama atau simultan berpengaruh positif dan signifikan terhadap kinerja karyawan PT. Surya Timur Sakti Jatim.

2. Hasil Uji $t$ bahwa Disiplin Kerja dan Kompensasi berpengaruh positif dan signifikan terhadap kinerja karyawan PT. Surya Timur Sakti Jatim. 
3. Berdasarkan perhitungan koefisien determinasi $\left(\mathrm{R}^{2}\right)$, maka diperoleh nilai Adjusted $R$ Square sebesar 0,473. Angka ini menjelaskan bahwa sebesar 47,3\% faktor-faktor kinerja karyawan pada PT. Surya Timur Sakti Jatim dapat dijelaskan oleh variabel Disiplin Kerja (X1) dan Kompensasi (X2). Sedangkan sisanya sebesar 52,7\% faktorfaktor lain yang tidak diteliti oleh peneliti dalam penelitian ini.

\section{DAFTAR PUSTAKA}

Arianto, D.A.N. 2013. Pengaruh Kedisiplinan, Lingkungan Kerja Dan Budaya Kerja Terhadap Kinerja Tenaga Pengajar. Jurnal Economia, Volume 9, Nomor 2, Oktober 2013, Hal:191-200

Aliya, S., \& Tobari, T. (2019) Pengaruh Pendidikan dan Pelatihan Terhadap Produktivitas Kerja Karyawan Bagian Produksi Pada PT. Semen Baturaja (Persero) Tbk Palembang. Jurnal Manajemen, Kepemimpinan, dan Supervisi Pendidikan, Volume 4, No.1, 97-103.

Apriani, D., \& Aliya, S. (2019) Pengaruh Disiplin Kerja dan Pelatihan Kerja Terhadap Prestasi Kerja Karyawan pada PT. Sriwijaya Palm Oil Grup Palembang. Prosiding Seminar Nasional Ekonomi dan Bisnis Global Competitive Advantage, Palembang: 3 Oktober 2019. Hal. 530-538.

El Karimah, Khoirunnisa. 2012. Hubungan Stres dengan Kepuasan Kerja Karyawan di Tiga Direktorat Operasional PT PLN (Persero). Skripsi Program Sarjana Ilmu Administrasi Negara, Depok: Universitas Indonesia.

Fording, Richard, 2011. "The Organization of Discipline : From Performance Management to Perversity and Punishment”, Oxford University Press on behalf of the journalof Public Administration Research and Theory, inc. Volume 21 suppl 2 April 2011.

Ghozali, Imam. (2011). Aplikasi Analisis Multivariate Dengan Program IBM SPSS 19 (Hasibuan, Malayu. (2014). Manajemen Sumber Daya Manusia. Jakarta: Bumi Aksara Diponegoro, Semarang.

Hariandja, Marihot, T.E., 2007. Manajemen Sumber Daya Manusia, Grasindo, Jakarta Hasibuan, Malayu SP, 2005. Manajemen Sumber Daya Manusia (Edisi Revisi), Penerbit Bumi Aksara, Jakarta

Hasibuan, Malayu. 2014. Manajemen Sumber Daya Manusia. Jakarta: Bumi Aksara

Kevin Haris Juhario (2015) Analisis Pengaruh Disiplin Kerja dan Imbalan terhadap Kinerja Karyawan PT. Bank Tabungan Negara Kantor Cabang Medan. Universitas Sumatera Utara.

Mangkunegara, AA Anwar Prabu, 2006. Evaluasi Kinerja SDM, Cetakan Kedua, Refika Aditama, Bandung.

Mangkuprawira, TB, Sjafri dan Aida Vitalaya Hubeis , 2007. Manajemen Mutu Sumber Daya Manusia, Cetakan Pertama, Ghalia Indonesia, Bogor.

Mondy, R. Wayne, 2008. Manajemen Sumber Daya Manusia, Edisi 10, Erlangga, Jakarta. 
Nawawi, Hadari, 2008. Manajemen Sumber Daya Manusia untuk Bisnis yang Kompetitif, Jilid satu, Cetakan Keempat, Gadjah Mada University Press, Yogyakarta:

Rivai, Veithzal, 2009. Kepemimpinan dan Perilaku Organisasi, Edisi Kedua, PT. Rajagrafindo Persada, Jakarta.

Sianturi, Palaria. 2011. Pengaruh Disiplin Kerja Terhadap Kinerja Karyawan (Studi Kasus Di Kantor PT PLN (PERSERO) Distribusi Jawa Barat dan Banten”, Jurnal telekom university, Vol 4

Simamora, Henry. 2004. Manajemen SDM, Yogyakarta : Sekolah Tinggi Ilmu Ekonomi YKPN.

Sugiyono, 2012. Metode Penelitian Penelitian Pendidikan (penelitian kuantitatif/kualitatif dan R\&D), Bandung : Alfabeta

Sukirman, 2011." Hubungan Kepuasan Kerja dan Disiplin Kerja Karyawan bagian Produksi PT Bintratx Semarang”, Jurnal Sosial dan Budaya, volume 4 nomor 1 halaman 13-23

Sutrisno, Edy, 2011. Manajemen Sumber Daya Manusia. Penerbit: Jakarta, Kencana.

Sutrisno, Edy, 2013. Manajemen Sumber Daya Manusia, Penerbit Kencana Prenada Media Group, Jakarta

Umar, Husein, 2008. Metodologi Penelitian untuk Skripsi dan Tesis Bisnis, Edisi Delapan, Rajawali Pers, Jakarta.

Umar, Gunu, 2010. "The Influence of Compensation on Performance of Sales Representatives of Pharmaceutical Companies Based In Ilorin - Nigeria”, an International Multi-Discriplinary Journal, Ethiopia Vol, 4 (3b) July 2010. 